\begin{tabular}{lll} 
KULTURA & $\begin{array}{l}\text { POLSKA AKADEMIA NAUK } \\
\text { KOMITET SOCJOLOGI }\end{array}$ & ISSN 0023-5172 \\
I & $\begin{array}{l}\text { INSTYTUT STUDIÓW POLITYCZNYCH } \\
\text { SPOLECENSTWO }\end{array}$ & \\
2009, n $4 \quad$ KULTURA (?) WIZUALNA & \\
\hline
\end{tabular}

KAROLINA J. DUDEK

Szkoła Nauk Spotecznych IFiS PAN

\title{
FILMY WESELNE. NOWE MEDIA A ZMIANY W RYTUALE*
}

\begin{abstract}
„Życie społeczeństw, w których panują nowoczesne warunki produkcji, przypomina olbrzymie zbiorowisko spektakli. Wszystko, co dawniej przeżywano bezpośrednio, oddaliło się, przybierając postać przedstawienia”.
\end{abstract}

Guy Debord

Jedną z funkcji rytuałów jest wprowadzanie zmian, przeobrażanie natury sacrum lub profanum zgodnie z potrzebami społecznymi (Caillois 1995, s. 24). W kulturze ludowej obrzędowe zmiany w świecie dokonywały się za sprawą słowa (por. Łeńska-Bąk 1999, s. 92). Miało ono ogromną moc. Żeby w pełni

Adres do korespondencji: karolina_dudek@vp.pl

* Praca naukowa finansowana ze środków na naukę w latach 2008-2009 jako projekt badawczy. Grant Ministerstwa Nauki i Szkolnictwa Wyższego nr N N109 243434 - „Analiza roli filmowca i znaczenia filmu weselnego we współczesnej kulturze typu ludowego", kierownik projektu badawczego dr Sławomir Sikora.

Prezentowany tekst powstał w toku seminarium „Nowe media w kulturze współczesnej” prowadzonego przez Marylę Hopfinger w Szkole Nauk Społecznych Instytutu Filozofii i Socjologii PAN. Pragnę podziękować Pani Profesor za inspirujące uwagi i ciekawą dyskusję. W toku rozważań odwołuję się do wyników badań, które prowadziłam razem ze Sławomirem Sikorą od 2006 r., najpierw podczas prac „Laboratorium etnograficznego: Wizualność w kulturze” (Instytut Etnologii i Antropologii Kulturowej Uniwersytetu Warszawskiego), a następnie realizując wyżej wymieniony grant. Na podstawie materiałów zebranych w ramach Laboratorium napisałam i obroniłam pracę licencjacką „Od rytuału do spektaklu - mediatyzacja obrzędów weselnych” (IEiAK UW, 2008). W ramach grantu zaś powstał także film antropologiczny Żeby to byto ciekawe... (realizacja: K. J. Dudek, S. Sikora; IEiAK UW, 2009; 73 minuty). Badania nad współczesną obrzędowością weselną oraz rolą fotografa i kamerzysty kontynuuję obecnie w formie projektu badawczego Muzeum Etnograficznego w Krakowie - „Wesela 21”. Moje szersze refleksje na temat wpływu nowych mediów na zmiany w rytuale weselnym zawierają artykuły w pokonferencyjnych zbiorach Ritual Today i Różne kultury, różne globalizacje (w druku). 
zrozumieć jego status i zakres owej mocy sprawczej, wystarczy przypomnieć sobie, jakie niebezpieczeństwa, według wierzeń w tradycyjnej kulturze ludowej, czekały na tych, którzy pomylili się odprawiając obrzęd ${ }^{1}$.

Współcześnie, w kulturze typu audiowizualnego, obrzędy stopniowo ulegają mediatyzacji, a media rytualizacji, co podkreśla Robert Dzięcielski (2004, s. 164) w podsumowaniu artykułu poświęconego uroczystemu wideofilmowaniu. Dzisiejsze rytuały coraz częściej są medialnymi lub przynajmniej zmediatyzowanymi spektaklami. Doświadczenia uczestnictwa zostają zapośredniczone przez obrazy, których oglądanie samo w sobie staje się coraz silniej skonwencjonalizowane. Czy są to rozgrywki sportowe, wystąpienia polityków czy ważne dla społeczeństwa wydarzenia o charakterze narodowym bierzemy w nich udział, siedząc przed telewizorem. Jak powiada Guy Debord (2006, s. 33): „Życie społeczeństw, w których panują nowoczesne warunki produkcji, przypomina olbrzymie zbiorowisko spektakli. Wszystko, co dawniej przeżywano bezpośrednio, oddaliło się, przybierając postać przedstawienia".

Coraz więcej aspektów rzeczywistości podporządkowanych jest zatem procesowi tworzenia jej wizualnych transpozycji. Dotyczy to w takim samym stopniu życia publicznego, jak i wydarzeń rodzinnych. Rytuał fotografowania i filmowania towarzyszy już, jak się wydaje, wszystkim etapom życia. Obok fotografii z uroczystości rodzinnych, które tradycyjnie dokumentowano, takich jak chrzest, ukończenie szkoły, ślub, na półkach domowych szafek coraz częściej pojawiają się amatorskie i profesjonalne filmy $-z$ porodów, studniówek i wesel. Chciałabym bliżej przyjrzeć się tym ostatnim. Ich pojawienie się i niezwykła popularność pozwala, jak sądzę, na opisanie i zdiagnozowanie pewnego szerszego zjawiska, które można określić mianem mediatyzacji rytuałów. Proponuję także potraktowanie tych produkcji filmowych jako szczególnej soczewki, przez którą można spojrzeć na pewne aspekty kultury audiowizualnej.

\section{PÓŁ KROKU WSTECZ, CZYLI O FOTOGRAFII WESELNEJ}

Zanim zaczęto dokumentować przemijanie życia na filmach, rolę skarbnicy wspomnień pełniły fotografie, które wcześniej zastąpiły pamięć (Sikora 2004, s. 9). Początkowo ślub i wesele upamiętniała pojedyncza fotografia wykonana $\mathrm{w}$ atelier. Posiadanie ślubnej fotografii było tak ważne, że jeżeli z jakichś po-

\footnotetext{
${ }^{1}$ Ciekawym współczesnym przykładem tego, jak ważne jest ścisłe trzymanie się „tekstu obrzędowego" (w tym szczególnym przypadku ów tekst to konstytucja), jest głośna sprawa przysięgi składanej powtórnie przez prezydenta Stanów Zjednoczonych Baracka Obamę. W czasie inauguracji przewodniczący Sądu Najwyższego John Roberts źle podyktował przyszłemu prezydentowi słowa. Wobec sugestii przeciwników prezydentury, że przysięga jest nieważna, uroczystość powtórzono; zob. AJK, Obama przysiega po raz drugi, „Gazeta Wyborcza”, 23 stycznia 2009, s. 1.
} 
wodów nie mogła być ona wykonana danego dnia, to upamiętniające zdjęcie robiono później ${ }^{2}$. Te pierwsze fotografie bardzo silnie podlegały obowiązującym wówczas konwencjom fotografowania. Roch Sulima (1987, s. 114) pisząc o fenomenie fotografii chłopskiej zauważa, że „chłop stając przed obiektywem, rzadziej wiejskiego, najczęściej małomiasteczkowego fotografa o d twa r z ał s obą wszystkie najistotniejsze modele własnego wyobrażenia siebie" ${ }^{3}$. Dziewiętnastowieczne fotografie kryły pewien paradoks — zdjęcia określonych osób były raczej wizerunkami pewnych typów niż obrazami przedstawiającymi indywidualne portrety postaci, innymi słowy — fotografowie, wykorzystując dostępne i czytelne kody obrazowej prezentacji, kreowali wizerunki, które miały nawiązywać do pewnego wzorca (Sztandara 2005, s. 128-131). Sulima (1987, s. 118) podkreśla także znaczenie odtwarzania zasad i hierarchii chłopskiego świata realizujących się poprzez powtarzalność i typowość przedstawień. Magdalena Sztandara (2005, s. 224) wyraża tę samą myśl nieco dobitniej — pisząc, że fotografie te redukują przedstawiane zjawiska i postaci, dążąc do schematyczności. Dzięki odpowiedniemu uteatralizowaniu tła, kompozycji i pozie modele przedstawiano takimi, jakimi ich sobie wyobrażano i jakimi oni wyobrażali sobie sami siebie (Sztandara 2005, s. 130). Atelier fotograficzne było zatem miejscem, w którym ludzie mogli kreować własny obraz, tworzyć tożsamość, „każda sesja "produkowała» pewne modelowe «dowody» postaci" (Sztandara 2005, s. 133). Rezultatem sesji weselnych również były modelowe świadectwa zawarcia związku małżeńskiego - hieratyczne, stojące prosto postaci, patrzące w obiektyw.

To, co typowe dla tradycyjnej fotografii chłopskiej — dążenie do odtworzenia pewnego idealnego konstruktu - w innym wydaniu pojawia się również później w filmie weselnym, który przedstawia wydarzenia w sposób schematyczny, odpowiadający pewnemu z góry przyjętemu scenariuszowi. Młoda para jest ukazywana w typowych pozach i w dającym się przewidzieć otoczeniu. Wszystkie te filmy są do siebie podobne, żeby nie powiedzieć - takie same: ten sam scenariusz, te same miejsca, podobna reżyseria zachowań. Zmieniają się tylko aktorzy, choć za każdym razem ona występuje w długiej białej sukni, a on w eleganckim garniturze. Wszystkie wesela wydają się sielankowe, ide-

2 Sławomir Sikora (2004, s. 117-118) przywołuje za Kirsten Hastrup przykład fotografii z chrztu wykonanej blisko cztery lata po fakcie. Zauważa, że fotografia niekiedy przedstawia bardziej prawdę idei, prawdę konwencji niż prawdę danego wydarzenia. Odsyła także do sceny z filmu Fortepian (reż. Jane Campion, 1993), w której pokazano, że fotografia wykonana w strojach ślubnych sankcjonuje zaaranżowany listownie związek.

3 Warto zauważyć, że również współcześnie pewne typy fotografii bywają wysoce skonwencjonalizowane. Badacze zajmujący się wschodnioazjatycką fotografią weselną podkreślają, że jej celem nie jest dokumentowanie wydarzenia, ale stworzenie, skonstruowanie wizerunku panny młodej. Co więcej za „ładne” uznaje się zdjęcie, które nie przedstawia zbyt wielu szczegółów. Dlatego bardzo często przy obróbce zdjęć wykorzystywane są takie efekty jak rozmycie i rozmazanie (por. Adrian 2006, s. 76; Lozada 2006, s. 90). 
alne. Film ten jest kulturową uroczystą autointerpretacją rzeczywistości (zob. Dzięcielski 2004, s. 163), do czego jeszcze wrócę.

Z czasem albumy weselne pęczniały, pojedyncze fotografie zaczynały się układać w całe sekwencje, ujmując coraz większą część wydarzeń, aż w końcu stały się fotonarracjami. Poniższe wypowiedzi fotografów oddają doskonale istotę zmiany, która się dokonała. Dzisiejsze albumy weselne liczą wprawdzie zwykle tylko kilkadziesiąt zdjęć, lecz ich cyfrowe, rozszerzone wersje przekazywane na płytach zawierają kilka setek zdjęć i stanowią bogate repozytorium obrazów utrwalających nawet najdrobniejsze szczegóły.

„Naprawdę był taki czas, że człowiek sobie wydzielał, jak zakładał film 36-klatkowy, to tak go zakładał do praktiki, bo praktika najbardziej oszczędzała film, że można było zrobić 39 zdjęć i na weselu na jednym ślubie $13 . .$. na drugim 13 , na trzecim 13, nie wolno było zmarnować jednej klatki, każde zdjęcie musiało być dobre, udane, ostre, dobrze skadrowane, prawidłowo naświetlone".

„Robiło się zdjęcia troszkę przed, na tych bramach, przygotowanie, sprzedaż, potem w kościele, a na weselu cały czas robiło się te 200 ujęć, załóżmy... to ten, to było wszystko i w sumie po kościele, po obiedzie, zrobiło się zdjęcia rodzinne ustawiane, potem parę w tańcu, potem był czas wolny do oczepin".

„Teraz tak się robi na weselach, oczywiście wybiera się później część z tych, obrabia się, do albumu... resztę się daje na płytce, więc takie minimum to jest takie 500, 700 zdjęć, więc w zasadzie to trzeba cały czas prawie pracować, tyle co człowiek siądzie odpocząć chwilę" 4 .

\section{FILMY VHS I DVD — REJESTRACJA I KREACJA}

Pierwsze filmy weselne były w dużej mierze ruchomym odpowiednikiem fotografii. Technika VHS w zasadzie nie dawała możliwości obróbki nagranego materiału. Narzucało to wiele ograniczeń i sprowadzało filmowanie do rejestrowania rytuału. Dominowały długie, statyczne ujęcia, dlatego filmy te są

${ }^{4}$ Cytaty pochodzą z wywiadów przeprowadzonych w czasie wskazanych na początku badań. Metodologia w obu projektach była dość złożona, łączyła metody tradycyjnych badań etnograficznych (swobodne wywiady pogłębione, obserwacja uczestnicząca), antropologii wizualnej (wywiady z użyciem filmu i fotografii, zapisy filmowe i fotograficzne), a także elementy etnografii internetu. W latach 2006-2008 powstała w efekcie bogata dokumentacja, między innymi wywiady (transkrybowane) i zapisy filmowe. Prowadziliśmy wywiady z kolbuszowskimi fotografami i wideofilmowcami, obserwowaliśmy sesje weselne w lokalnym skansenie, uczestniczyliśmy w weselu, obserwowaliśmy powstawanie filmu weselnego (od rejestracji do "gotowego produktu"), wiele godzin spędziliśmy też na obserwacji codziennej pracy w zakładzie oferującym usługi fotograficzne i wideofilmowania; prowadziliśmy również rozmowy z różnymi usługodawcami zaangażowanymi w organizację wesel, a także z uczestnikami wesel (zarówno z młodymi parami, jak i gośćmi). Jeśli chodzi o materiał wizualny, to analizowaliśmy zarówno materiały wytworzone (własne rejestracje, na przykład sesji w skansenie), jak i materiały zastane (fotografie ślubne i filmy weselne). Więcej informacji można znaleźć na stronie Sławomira Sikory, kierownika obu projektów: www.slawomir-sikora.net, a także w jego artykule Ktopoty ze zbyt bliska kultura albo antropologia na wtasnym podwórku (w druku). 
nazywane przez fotografów „tasiemcami”. Etap „postprodukcji” odbywał się przed nagraniem materiału $z$ wesela i sprowadzał się do przygotowania czołówki filmu, którą nagrywano na kasetę wkładaną następnie do kamery. Nagrywany w czasie ślubu i wesela materiał nie podlegał żadnym dalszym obróbkom, w związku z czym gotową kasetę z filmem weselnym przekazywano młodej parze zaraz po nakręceniu ostatniego ujęcia. Istniały wprawdzie pewne techniczne możliwości montażu obrazu i dogrywania muzyki za pomocą prostych mixerów dźwięku i obrazu ${ }^{5}$. Efekt? Zwielokrotnione obrazy młodej pary pojawiają się na tle animacji wirujących abstrakcyjnych figur - latających kul i obracających się ostrosłupów - lub na tle wodospadu, w którym woda płynie do góry. Estetyka wykreowanego w ten sposób obrazu przypomina znane teledyski przełomu lat osiemdziesiątych i dziewięćdziesiątych, takie jak chociażby Orinoco Flow Enyi czy Papua New Guinea The Future Sound of London. Jednak mimo tych możliwości pracy nad obrazem w epoce VHS polscy kamerzyści weselni swoje produkcje realizowali raczej w realistycznej konwencji wideoreportażu.

Pojawienie się technologii cyfrowej wprowadziło ogromne zmiany w sposobach realizowania filmów weselnych. Dziś są to montowane z wykorzystaniem nie tylko korekcji barwnej i podstawowych łączeń optycznych, ale także cyfrowych animacji i różnych efektów specjalnych, składające się z wielu pojedynczych ujęć, wyreżyserowane multimedialne kolaże, które w coraz większym stopniu przypominają raczej wideoklipy z MTV niż wcześniejsze surowe filmy VHS. „Obraz elektroniczny można elektronicznie przetwarzać kreując nową, nieistniejącą przed kamerą rzeczywistość. Można tworzyć nieistniejące scenerie, usuwać ludzi i przedmioty z kadru lub wprowadzać obiekty i osoby dokładnie w te miejsca na taśmie, które sobie wymarzyliśmy" — mówił o możliwościach nowej technologii Zbigniew Rybczyński (Kornatowska 1993, s. 39). Kamerzyści weselni doskonale zdają sobie $z$ tego sprawę i potrafią te możliwości wykorzystać. Poniższy cytat należy traktować raczej nie jako zabawną dykteryjkę odsłaniającą kulisy realizacji filmów weselnych, lecz dobitny przykład ukazujący zmianę świadomości ich twórców.

„Według mnie, no oczywiście różne są szkoły, dla mnie taki plener to jest dla państwa młodych, żeby fotograf zrobił więcej zdjęć, to się weźmie tych starostów i drużbów, no bo zawsze coś pstryknie, ale zasadniczo, sami młodzi... Z młodymi można coś wykombinować powiedzieć: «Słuchajcie, idźcie tędy. Tu się zatrzymajcie, popatrzcie na staw. Będziecie się cieszyć, że widzicie łabędzie». Nie ma wprawdzie łabędzi, ale to nic nie szkodzi, prawda? Weźmie się z poprzedniego nagrania łabędzie... «Wy będziecie rzucać chleb, a z poprzedniego wesela, prawda, się wmontuje łabędzie, które jedzą chleb. Kto będzie wiedział, który to chleb jedzą? Nikt nie będzie wie-

5 Co możemy zobaczyć choćby na filmie Silk, Muthappar and VHS. Portraits from South India (realizacja D. Lüthi, U. Grossenbacher, 1997). Z filmu korzystałam dzięki uprzejmości Damaris Lüthi, która mi go udostępniła. 
dział!» No takie kombinacje się czasami robi. Był okres, że były dwa łabędzie stare i siedem młodych - no to był widok piękny. Tam pod ławką zawsze chleb leżał już przygotowany, tak że jak młodzi przyjdą, to będą mieli co rzucać".

\section{WESELE JAK Z FILMU...}

Cyfrowy montaż rzucił wyzwanie surowemu realizmowi wczesnych filmów weselnych. Prawda rzeczywistych wydarzeń musiała ustąpić miejsca prawdzie nowej formuły filmu weselnego, choć nie zrezygnowano $z$ realistycznych inspiracji wcześniejszego okresu. Owo realistyczno-dokumentalne residuum zyskało jednak nową, cyfrową oprawę. Ów typ realizmu określiłabym - za autorami artykułu na temat realizmu jako formy kulturowej (Abercrombie, Lash, Longhurst 2004) - mianem realizmu przerobionego. Zauważają oni, że przez ostatnie dwieście lat realizm był dominującą formą kulturową i że większość współczesnej produkcji telewizyjnej naśladuje realistyczne konwencje, (Abercrombie, Lash, Longhurst 2004, s. 391-392). Ich zdaniem istnieją trzy główne wyznaczniki realizmu, które odnajdziemy w tego typu przestawieniach. Po pierwsze, „realizm podaje się za okno na świat”. Po drugie, wykorzystuje się opowiadanie, które ma racjonalnie uporządkowaną, rozwijająca się zgodnie z zasadą przyczyna-skutek fabułę, i w którym można wydzielić początek, środek i koniec. Po trzecie, maskuje się autorstwo i proces produkcji. W filmie weselnym epoki cyfrowej znajdziemy wszystkie te elementy (Abercrombie, Lash, Longhurst 2004, s. 387).

Na początku filmów prawie zawsze pojawiają się plansze informujące widza, że będzie oglądał „reportaż wideo z uroczystych zaślubin”. Słowo „reportaż” jest tu znamienne, gdyż sugeruje, że mamy do czynienia $z$ obiektywną rejestracją wydarzeń. Film weselny przedstawia wszystkie wydarzenia chronologicznie. Wprowadza najważniejszych bohaterów, przedstawiając ich w specjalnie wydzielonej części filmu, w której obok zbliżenia-portretu danej osoby pojawia się imię i nazwisko oraz funkcja pełniona przez nią na weselu (np. drużba, starościna itd.). „To wyglądało jak Polska telenowela jak «Klan» albo «Moda na sukces», że twarz i... "Anna Kowalska ${ }^{6}$ — panna młoda»" — komentowała pewna osoba po obejrzeniu filmu ze swojego wesela. Dodane tło muzyczne maskuje działanie kamerzysty, który reżyserował zachowania młodej pary i ukrywa proces powstawania poszczególnych ujęć. W ten sposób film próbuje się podać za obiektywną rejestrację rzeczywistości. Jest to jednak, powtórzę raz jeszcze, realizm pozorny, przerobiony. Film weselny pokazuje świat zinterpretowany (poddany dopasowaniu do norm narzucanych przez konwencję) i jest to obraz w dużej mierze wykreowany.

\footnotetext{
${ }^{6}$ Dane zmienione.
} 
Kreacja w filmie weselnym zachodzi na wielu poziomach. Nie można jednak mówić o niej w oderwaniu od refleksji na temat współczesnych wesel. Dzisiejsze obrzędy weselne to nie tylko bricolage $z$ elementów pochodzących $z$ różnych tradycji, zarówno polskich, jak i zaczerpniętych $z$ najodleglejszych zakątków świata, to także układanka $z$ elementów dostępnych w świecie mediów, gdyż odnajdziemy $\mathrm{w}$ nich wiele zapożyczeń z obrazów telewizyjnych, filmowych, reklamowych. Podobnie jest z filmami weselnymi. „Globalizacja i technologia tworzą świat, w którym wszystko może stać się tworzywem”, jak powiada Gordon Mathews (2000, s. 99). To świat, w którym tradycyjne role producentów i konsumentów mediów zostały przedefiniowane (zob. Jenkins 2007, s. 9). Dziś jednych i drugich należy raczej postrzegać jako współuczestników medialnego dyskursu wchodzących ze sobą w interakcje. Ową cyrkulację treści między różnymi systemami medialnymi i jej zależność od aktywnego udziału konsumentów Henry Jenkins (2007) nazywa konwergencją.

Doskonałym przykładem takiej cyrkulacji treści są rekonstrukcje scen filmowych wplecione w sam obrzęd i film weselny. Przede wszystkim mam tu na myśli inscenizację pierwszego tańca młodej pary, a zwłaszcza jego najpopularniejszą aranżację według sceny z filmu Dirty Dancing, w której para filmowych bohaterów, Johnny (Patrick Swayze) i Baby (Jennifer Grey), tańczy na pożegnalnym pokazie ${ }^{7}$. Po niezwykłym sukcesie, mierzonym liczbą doniesień prasowych i telewizyjnych, a także liczbą wyświetleń, zamieszczonego na platformie YouTube fragmentu filmu weselnego rejestrującego pierwszy taniec w stylu Johnny\&Baby przez londyńską parę Julię Boggio i Jamesa Derbyshire, wiele par na całym świecie zdecydowało się na podobną rekonstrukcję, o czym można się przekonać przeglądając serwis YouTube za pomocą hasła wyszukiwawczego „wedding Dirty Dancing” (lub podobnych). Podobnym przykładem, choć w moim odczuciu nieco zaskakującym, są rekonstrukcje układu tanecznego z teledysku Thriller Michaela Jacksona.

$\mathrm{Na}$ wzór scen filmowych, a dokładniej pewnych konkretnych kadrów, wykonywane są również pojedyncze ujęcia do filmu weselnego lub pamiątkowe zdjęcia. W czasie realizacji filmu weselnego, który stał się podstawą antropologicznego dokumentu o mediatyzacji obrzędów weselnych, kamerzystka poprosiła młodą parę, żeby „zrobili Titanica”. Ów skrót myślowy został bezbłędnie odczytany. Nowożeńcy rozpostarli ramiona jak w scenie filmowej z filmu Titanic, w której Rose i Jack stoją na dziobie statku.

W filmie weselnym pojawiają się jednak nie tylko rekonstrukcje poszczególnych scen. Niekiedy całe filmy bądź znaczne ich części realizowane są na wzór jakiegoś filmu. „Film ślubny inaczej” — tak nazywa nowy wątek na forum wideofilmowców twórca filmu weselnego w stylu Władcy Pierścieni ${ }^{8}$. W poście

${ }^{7}$ Szerzej zob. w moim tekście: Globalny kontekst lokalności - filmy weselne, który ukaże się w tomie Różne kultury, różne globalizacje (w druku).

8 Forum portalu Światobrazu - www.swiatobrazu.pl 
zamieszczonym przez niego $\mathrm{w}$ internecie pojawia się link do filmu i prośba o komentarz ${ }^{9}$. „Historia ta wydarzyła się w niegdyś pięknej, spokojnej i szczęśliwej krainie — Śródziemiu, gdzie panowała radość i pokój, a wszystko wypełnione było słońcem, miłością i śpiewem ptaków. Nie trwało to wiecznie. Pewnego dnia w krainie Śródziemia zległy cienie i nastały mroczne czasy. Świat się zmienił. Nikt już dokładnie nie pamięta ani jak, ani kiedy" - narratorka filmu snuje opowieść spokojnym głosem. Przed naszymi oczami wyłania się dzika przyroda. Zimny krajobraz spowity jest gęstą mgłą, co przydaje mu aury tajemniczości i grozy. Jeden $z$ forumowiczów krytykuje głos lektorki jako zbyt monotonny. Twórca filmu wyjaśnia w odpowiedzi, że lektorka to profesjonalistka $z$ jednego $z$ warszawskich banków głosów, „a treść tak właśnie miała brzmieć, obejrzyjcie władcę pierścieni, to dokładnie ten charakter i ten głos, choć we władcach jest jeszcze bardziej głębszy, nużący, trochę zwiększyliśmy tempo. Wstępnie miała być pani Krystyna Czubówna, lecz za bardzo kojarzyła by się $z$ «national geographic» a po za tym kosztowała 4 razy więcej”. Główni bohaterowie to Agnieszka i Michał, którym towarzyszy rycerska drużyna grana przez statystów ze stowarzyszenia „Drużyna Grodu Trzygłowa” ze Szczecina, którzy zatrudnieni byli także przy realizacji filmu Wiedźmin. Imiona bohaterów wyryte są na dwóch pierścieniach (są to oryginalne obrączki młodej pary), które pojawiają się $\mathrm{w}$ animacji na wzór Wtadcy Pierścieni. „Dwa pierścienie, by wszystko naprawić, dwa - by oboje odnaleźć, dwa - by oboje połączyć, i w małżeństwie na wieki związać" - opowiada dalej narratorka. W filmie weselnym oba wątki (baśniowy, wzorowany na filmie oraz reportaż weselny) są ze sobą splecione. Wpisanie opowieści o weselu w tak szczególny kontekst było pomysłem młodej pary.

Scena z Dirty Dancing lub Thrillera jako pierwszy taniec, film weselny w stylu Wtadcy Pierścieni z mocnym akcentem rodem $z$ Wiedźmina... A co z polską tradycją? Czy rozwój mediów ją niszczy? John Thompson (2006, s. 184-185, 190) zauważa, że choć wielu teoretyków żywi przekonanie, że rozwojowi nowoczesnych społeczeństw będzie towarzyszył upadek roli tradycji, to jego zdaniem jest wręcz przeciwnie. Rozwój mediów raczej tchnął w nią nowe życie. Mediatyzacja uwolniła tradycję od ograniczeń związanych z bezpośrednim przekazem. Thompson uważa, że istota zmiany polega nie na jej zniszczeniu, ale na oderwaniu od korzeni. Nowe media pozwalają na uniezależnienie przekazu tradycji od wymogu współobecności. Filmy weselne przesyłane znajomym w najodleglejszych zakątkach globu, zamieszczane w internecie, na platformach takich jak YouTube, stanowią pas transmisyjny starych i nowych tradycji. Przyczyniają się bowiem nie tylko do swego rodzaju „popularyzacji” pewnych zwyczajów, ale także aktywnie wpływają na tworzenie się zupełnie nowych elementów rytuału.

\footnotetext{
${ }^{9}$ http://www.vimeo.com/3530139
} 


\section{PERFORMATYWNOŚĆ I MAGIA DOBREGO POCZĄTKU}

Powyższe przykłady pokazują, że współczesny film weselny prezentuje pewną szczególną rzeczywistość - wyidealizowany obraz wesela, zawierający często odwołania do znanych przedstawień filmowych. Do tego należy dodać silnie skonwencjonalizowaną reżyserię zachowań, wycinanie $z$ filmu wszelkich „potknięć” i „wpadek” czy rozmaite korekty estetyczne stosowane w trakcie montażu, mające na celu poprawienie jakości obrazu. Działania takie można tłumaczyć faktem, że filmy te mają być oglądane przez rodzinę i lokalną społeczność, a zatem powinny być ciekawe, „dobrze oglądające się” i nie powinny zawierać scen w jakikolwiek sposób niezręcznych czy zawstydzających. Trudno nie zgodzić z taką interpretacją. Etnograf pytający rozmówców o film weselny również usłyszy podobne odpowiedzi. Sprawa wydaje się więc oczywista i tym samym zamknięta. Czy jednak za takimi racjonalizacjami nie kryje się coś jeszcze? Przyjrzyjmy się temu ukrytemu poziomowi nieoczywistych znaczeń.

Katarzyna Łeńska-Bąk (1999, s. 89) stwierdza, że celem zarówno tradycyjnego obrzędu weselnego, jak i jego nowoczesnej formy jest dokonywanie i sankcjonowanie zmian w świecie. „Tradycyjny obrzęd był performatywny, ponieważ jego istotą była rzeczywista (w tamtej kulturze) moc sprawczo-kreacyjna działań obrzędowych uruchamiających moce magiczne, przywołujących mityczny porządek i rozgrywały się one w reaktualizowanej mitycznej czasoprzestrzeni" — pisze badaczka (Łeńska-Bąk 1999, s. 90). Podobną myśl znajdujemy u Erica W. Rothenbuhlera (2003, s. 63), który podkreśla, że ważne rytuały działają jak rodzaj społecznego steru. Ich zadaniem nie jest wyrażanie świata takiego, jakim jest, lecz raczej takiego, jakim powinien być. W celu zilustrowania tej tezy podaje przykład wypowiedzi pastora. Stwierdzenie „miłość nigdy nie zazdrości” nie jest opisem świata, rzeczywistego stanu rzeczy, lecz moralnym zaleceniem.

Powróćmy jednak do pojęcia performatywności, którym posługuje się Łeńska-Bąk. Wprowadził je angielski filozof John Langshaw Austin na oznaczenie zmian dokonywanych $\mathrm{w}$ otaczającej rzeczywistości za pomocą odpowiednich użyć języka (Austin 1993, s. 311-335; Łeńska-Bąk 1999, s. 89-90; Culler 1998, s. 110-124; Schechner 2006, s. 146-148). Odróżnił on wypowiedzi performatywne (performatywy) od zwykłych konstatacji, które opisują jakiś stan rzeczy i mogą być prawdziwe lub fałszywe. Performatywy de facto wykonują czynność, którą oznaczają, jednocześnie nie są ani prawdziwe, ani fałszywe. Wypowiedzi te mogą być jednak w zależności od okoliczności „fortunne” lub „niefortunne”. Austin (1993, s. 110) objaśniając rolę owych szczególnych użyć języka podaje przykład ceremonii zaślubin. Kiedy ksiądz pyta: „Czy chcesz pojąć tę oto kobietę za swą prawowitą małżonkę?”, a pan młody odpowiada: „Tak”, tym samym wstępuje $\mathrm{w}$ związek małżeński. Taka wypowiedź jest $\mathrm{w}$ rozumieniu Austina fortunna. Jeśli jednak mężczyzna jest już żonaty albo jeśli osoba udzielająca ślubu nie ma do tego uprawnień, to stwierdzenie „Tak” nie skutkuje zawarciem związku. O takich wypowiedziach performatywnych angielski filozof 
powiada, że są niefortunne. Pojęcie performatywności rozwinął Jacques Derrida, dowodząc, że wypowiedź perfomatywna może mieć moc sprawczą tylko wtedy, gdy istnieją iterowalne modele wypowiedzi, inaczej mówiąc wypowiedzi performatywne mogą działać tylko wtedy, gdy zostaną rozpoznane jako cytaty zwyczajowych formuł (zob. Culler 1998, s. 115). „Język jest performatywny w tym sensie, że nie przekazuje po prostu informacji, lecz dokonuje różnych aktów, przez powtarzanie ustalonych praktyk dyskursywnych bądź sposobów działania" (Culler 1998, s. 115).

Analogicznie, gdyż „przeniesienie pojęcia performatywności języka w dziedzinę działań obrzędowych jest od początku do końca jedynie analogią" (Buchowski 1993, s. 131; por. Łeńska-Bąk 1999, s. 90), performatywna moc rytuału leży w jego zdolności do przekształcania rzeczywistości, zmiany stanu, biorącej w nim udział młodej pary. Rytuał, aby był performatywny, musi spełniać podobne warunki jak wypowiedź. Zatem musi również istnieć pewna ogólna iterowalność obrzędu, podobnie jak konieczne jest, by istniały powtarzalne praktyki wypowiedzi.

Dawne rytuały weselne odprawiane według powtarzalnych scenariuszy miały ową moc sprawczą. Dzisiejsze zbanalizowane, kiczowo-synkretyczne obrzędy, pisze Łeńska-Bąk (1999, s. 94), zawierają wprawdzie elementy performatywności, ale jest to innego typu sprawczość. Dawniej realizowała się ona w słowie i działaniu obrzędowym, które cechowała udramatyzowana forma (Baudouin de Courtenay-Ehrenkreutz-Jędrzejewiczowa 2005). Dziś weselne przyśpiewki są już dawno zapomniane, tylko czasami odśpiewuje się je z kartki dla urozmaicenia obrzędu. Działania obrzędowe zaś sprowadzone są do sceny-znaku zaaranżowanej na potrzeby filmu weselnego. Bardzo często są to, powtórzę raz jeszcze, elementy zaczerpnięte $z$ różnych tradycji lub wręcz inspirowane przez obrazy z filmów czy reklam pełniące funkcję estetyczną (Łeńska-Bąk 1999, s. 18, 36). Nie mają one tej dawnej mocy sprawczej. Jednak zasada performatywności rytuału, moim zdaniem, pozostaje zachowana. Jest ona tylko realizowana innymi środkami. W filmie weselnym odnajdziemy pewne iterowalne sekwencje obrazów. Każdy z nich mówi o weselu tymi samymi obrazo-słowami, w każdym z nich zobaczymy pewien powtarzalny zestaw dekoracji i rekwizytów. W każdym pojawią się również gesty i pozy — obejmowanie się, przytulanie, podnoszenie w górę partnerki, pocałunki, o których przez cały czas nagrywania filmu przypomina co chwilę „reżyser”. Zmieniają się tylko aktorzy. Moc sprawczą ma dziś zatem obraz — zmediatyzowana wersja rytuału, poprzez którą zapośredniczone jest performatywne działanie obrzędu.

W wyidealizowanej filmowej wersji wesela realizuje się zatem magia dobrego początku. Gest stwarzania jest działaniem o charakterze paradygmatycznym — coś jest takie, jakim zostało stworzone. Dobry początek — udane wesele to udane małżeństwo. Magia dobrego początku jest wzmacniana przez mediatyzowaną pamięć. Najpierw fotografia, a potem film weselny do pewnego stopnia pamięć zastąpiły, choć nie są oczywiście jedynymi dostępnymi formami zacho- 
wania obrazu wesela dla potomnych. Szwedzka badaczka Eva Knuts (2008) pisze na przykład o „weselnych pudełkach” i „księgach wspomnień” 10 . Zdaniem Knuts nie są one niewinnymi przedmiotami, które jedynie podtrzymują i wzmacniają działanie pamięci. Badaczka podkreśla ich aktywną rolę w kształtowaniu pamięci, zwłaszcza „dobrej pamięci”, w zachowaniu wyidealizowanej wizji wesela. Filmy weselne analogicznie — odpowiednio wyreżyserowane i zmontowane - służą zachowaniu „dobrego wspomnienia wesela”, które jest niezbędne do działania magii dobrego początku.

\section{RYTUAE W ZMEDIATYZOWANYM ŚWIECIE}

Mediatyzacja rytuałów weselnych związana jest z bardzo głębokimi przemianami kulturowymi. Zmiany te sięgają podstaw widzenia świata - „typu racjonalności, sposobów «organizowania» Kosmosu, struktury wartości, przeświadczeń na temat mechanizmów rządzących światem i historią" (Łeńska-Bąk 1999, s. 33). Jeżeli przyjmiemy za Michaelem Herzfeldem (2004, s. 299), że nie można programowo odrzucać pojęcia „kosmologia” w odniesieniu do nowoczesnego, „odczarowanego” świata, to próbę odpowiedzi na pytanie, „dlaczego współcześnie rytuały ulegają mediatyzacji?”, należałoby poprzedzić pytaniem — „W jakim kosmosie jesteśmy zanurzeni?”

Kosmologię, która wprowadza ład w naszą rzeczywistość i do której chciałabym się w tym miejscu odwołać, najpełniej oddaje heideggerowskie pojęcie „światoobrazu” (Heidegger 1977). Począwszy od średniowiecza mamy do czynienia $z$ procesem zmniejszania się roli zmysłów niewizualnych w kulturze europejskiej (Herzfeld 2004, s. 347). Rozwój techniki fotograficznej, a później filmowej, sprawił, że obrazy wypełniły, a następnie zakryły świat. Codziennie jesteśmy nimi bombardowani, w takim stopniu, że przywykliśmy widzieć poprzez nie świat (Okely 2005, s. 18; Gombrich 1993, s. 23). Dzięki obrazom możemy być wszędzie obecni, ale jest to obecność fantomatyczna (por. Hopfinger 2003, s. 148). To szaleństwo wizualizacji zmienia status ontologiczny rzeczywistości. Światoobraz nie oznacza „obrazu świata, lecz świat pojmowany jako obraz”, powiada Martin Heidegger (1977, s. 142). To, że „bycia bytu poszukuje się i znajduje się je w tym, że jest on przedstawiany”, „czyni epokę, w której to następuje, epoką nową w porównaniu z poprzednią" (Heidegger 1977, s. 142-143). Histeria reprodukcji rzeczywistości w obrazach sprawia, że rzeczywistość znika i ustępuje miejsca obrazowi, który jest bardziej rzeczywisty niż ona sama (Baudrillard 2005, s. 174). „Rzeczy realnie przeżywane wydają się nierealne i zachowują swój nierealny status, dopóki same nie przyjmą formy telewizyjnych obrazów — powiada Zygmunt Bauman (2006, s. 131). Żeby nadać realność własnemu życiu, trzeba je najpierw sfilmować wideokamerą i utrwa-

10 Chciałabym podziękować prof. Barbarze Czarniawskiej za zwrócenie uwagi na prace Knuts. 
lić na taśmie". W takim świecie rytuał musiał być zmediatyzowany. Stał się spektaklem, którego obraz ma magiczną moc strukturowania świata.

\section{BIBLIOGRAFIA}

Abercrombie Nicolas, Lash Scott, Longhurst Brian, 2004, Przedstawienia popularne: przerabianie realizmu, w: Ryszard $\mathrm{Nycz}$ (red.), Odkrywanie modernizmu. Przekłady $i$ komentarze, Universitas, Kraków.

Adrian Bonnie, 2006, Geographies of Style: Taiwan's Bridal Photography Empire, „Visual Anthropology", nr 19, s. 1-13.

AJK, 2009, Obama przysiega po raz drugi, „Gazeta Wyborcza”, 23 stycznia.

Austin John Langshaw, 1993, Mówienie i poznawanie. Rozprawy i wykłady filozoficzne, tłum. Bogdan Chwedeńczuk, Wydawnictwo Naukowe PWN, Warszawa.

Baudouin de Courtenay-Ehrenkreutz-Jędrzejewiczowa Cezaria, 2005, Łańcuch tradycji. Teksty wybrane, Wydawnictwa Uniwersytetu Warszawskiego, Warszawa.

Baudrillard Jean, 2005, Symulakry i symulacja, tłum. Sławomir Królak, Sic!, Warszawa.

Bauman Zygmunt, 2006, Płynna nowoczesność, tłum. Tomasz Kunz, Wydawnictwo Literackie, Kraków.

Buchowski, 1993, Magia i rytuat, Instytut Kultury, Warszawa.

Caillois Roger, 1995, Cztowiek i sacrum, tłum. Anna Tatarkiewicz, Ewa Burska, Volumen, Warszawa.

Culler Jonathan, 1998, Teoria literatury, tłum. Maria Bassaj, Prószyński i S-ka, Warszawa.

Debord Guy, 2006, Spoteczeństwo spektaklu oraz Rozważania o spoteczeństwie spektaklu, tłum. Mateusz Kwaterko, PIW, Warszawa.

Dudek Karolina J., w druku, Globalny kontekst lokalności - filmy weselne, w: Waldemar Kuligowski, Adam Pomieciński (red.), Różne kultury, różne globalizacje, Poznań.

Dudek Karolina J., w druku, Media, Rituals and Images of the Modern Wedding, w: Ritual Today, Kraków.

Dzięcielski Robert, 2004, Uroczyste wideofilmowanie. Kilka uwag etnografa, w: Grzegorz Pełczyński, Ryszard Vorbrich (red.), Antropologia wobec fotografii i filmu, Biblioteka Telgte, Poznań.

Gombrich Ernst, 1993, Obraz wizualny, tłum. Agnieszka Morawińska, w: Jadwiga Bocheńska, Alicja Kisielewska, Mirosław Pęczak (red.), Wiedza o kulturze, cz. IV: Audiowizualność w kulturze, Wydawnictwo Uniwersytetu Warszawskiego, Warszawa.

Heidegger Martin, 1977, Czas światoobrazu, tłum. Krzysztof Wolicki, w: Martin Heidegger, Budować, mieszkać, myśleć. Eseje wybrane, Czytelnik, Warszawa.

Herzfeld Michael, 2004, Antropologia. Praktykowanie teorii w kulturze i spoteczeństwie, thum. Maria M. Piechaczek, Wydawnictwo Uniwersytetu Jagiellońskiego, Kraków.

Hopfinger Maryla, 2003, Doświadczenie audiowizualne. O mediach $w$ kulturze wspótczesnej, Sic!, Warszawa.

Jenkins Henry, 2007, Kultura konwergencji. Zderzenie starych i nowych mediów, tłum. Małgorzata Bernatowicz, Mirosław Filiciak, Wydawnictwo Akademickie i Profesjonalne, Warszawa.

Knuts Eva, 2008, Wedding in a Box Foldings of Time and Space, w: Helene Brembeck, Karin M. Ekström, Magnus Mörck (red.), Little Monsters: Decoupling Assemblages of Consumption, LIT Verlag, Berlin-Hamburg-Münster. 
Kornatowska Maria, 1993, Rozmowa w Nowym Jorku (ze Zbigniewem Rybczyńskim), w: Zbigniew Rybczyński, Podróżnik do krainy niemożliwości. Wokót twórczości Zbigniewa Rybczyńskiego, Zbigniew Benedyktowicz (red.), Instytut Sztuki PAN - Komitet Kulturoznawstwa, Warszawa.

Lozada Eriberto P., 2006, Framing Globalization: Wedding Pictures, Funeral Photography, and Family Snapshots in Rural China, „Visual Anthropology”, t. 19, s. 87-103.

Łeńska-Bąk Katarzyna, 1999, Zapraszamy na wesele... Weselne oracje i ceremonialne formuty, Wydawnictwo Uniwersytetu Jagiellońskiego, Kraków.

Mathews Gordon, 2000, Supermarket kultury. Kultura globalna a tożsamość jednostki, tłum. Ewa Klekot, PIW, Warszawa.

Okely Judith, 2005, Wizualizm i krajobraz: patrzeć $i$ widzieć $w$ Normandii, tłum. Iwona Kurz, „Konteksty. Polska Sztuka Ludowa”, nr 4.

Rothenbuhler Eric W., 2003, Komunikacja rytualna: od rozmowy codziennej do ceremonii medialnej, tłum. Janusz Barański, Wydawnictwo Uniwersytetu Jagiellońskiego, Kraków.

Schechner Richard, 2006, Performatyka: wstęp, tłum. Tomasz Kubikowski, Ośrodek Badań Twórczości Jerzego Grotowskiego i Poszukiwań Teatralno-Kulturowych, Wrocław.

Sikora Sławomir, 2004, Fotografia. Między dokumentem a symbolem, Świat Literacki, Instytut Sztuki PAN, Izabelin.

Sikora Sławomir, w druku, Kłopoty ze zbyt bliska kultura albo antropologia na własnym podwórku. Przypadek filmowy, w: Anna Malewska-Szałygin (red.), Antropologia wobec wspótczesności.

Sulima Roch, 1987, Fotografia chtopów polskich, „Konteksty. Polska Sztuka Ludowa”, nr $1-4$.

Sztandara Magdalena, 2006, Fotografia etnograficzna i „etnograficzność” fotografii. Studium $z$ historii myśli etnologicznej i fotografii II poł. XIX i I pot. XX wieku, Wydawnictwo Uniwersytetu Opolskiego, Opole.

Thompson John B., 2006, Media i nowoczesność. Społeczna teoria mediów, tłum. Izabela Mielnik, Astrum, Wrocław.

Zawojski Piotr, 1995, Filmowy obrazoświat jako produkt symulacji elektronicznej, „Kwartalnik Filmowy", nr 11.

http://www.swiatobrazu.pl

http://www.vimeo.com

http://www.youtube.com

\section{WEDDING VIDEOS: NEW MEDIA AND CHANGES IN RITUAL}

\section{Summary}

Nowadays rituals are caught up in the process of mediatization. Wedding films are a perfect example of it. The author explores certain aspects of audiovisual culture the circulation of symbolic content, the meaning of tradition, new ways of creating audiovisual narratives. Analysing selected examples, she discusses new, digital forms of expression and their meaning in the ritual. 


\section{Key words/słowa kluczowe}

ritual / rytuał; wedding film / film weselny, visuality in culture / wizualność w kulturze, visual anthropology / antropologia wizualna, anthropology of modern times / antropologia współczesności 